Article

\title{
The Application of Supercritical Carbon Dioxide and Ethanol for the Extraction of Phenolic Compounds from Chokeberry Pomace
}

\author{
Łukasz Woźniak $^{1, *}$, Krystian Marszałek ${ }^{1}$, Sylwia Skąpska ${ }^{1}$ and Renata Jędrzejczak ${ }^{2}$ \\ 1 Department of Fruit and Vegetable Product Technology, Institute of Agricultural and Food Biotechnology, \\ 36 Rakowiecka St., Warsaw 02-532, Poland; marszalek@ibprs.pl (K.M.); skapska@ibprs.pl (S.S.) \\ 2 Department of Food Analysis, Institute of Agricultural and Food Biotechnology, 36 Rakowiecka St., \\ Warsaw 02-532, Poland; renata.jedrzejczak@ibprs.pl \\ * Correspondence: lukasz.wozniak@ibprs.pl; Tel.: +48-22-604-3604
}

Academic Editor: Jose Augusto Paixao Coelho

Received: 22 December 2016; Accepted: 21 March 2017; Published: 25 March 2017

\begin{abstract}
Chokeberry (Aronia melanocarpa (Michx.) Elliot) is a fruit with exceptionally high levels of phenolic compounds which are accumulated mainly in the peel; hence, the majority remains in the leftovers after juice production. Extraction with the use of carbon dioxide in supercritical conditions was used to isolate phenolic compounds from the pomace. The effect of the process parameters (temperature; pressure; and the addition of ethanol) on the extraction yields and properties of the extracts was investigated. The anthocyanin and total phenolic compound content, as well as the scavenging activity against five selected radicals, were evaluated. The best results were acquired for $35^{\circ} \mathrm{C}, 10 \mathrm{MPa}$, and $80 \% \mathrm{~m} / \mathrm{m}$ ethanol addition, the yield of phenolic compounds was $1.52 \mathrm{~g}$ per $100 \mathrm{~g}$ of pomace. The amount of extracted phenolics and the antioxidative attributes of the extracts were highly correlated. The impact of supercritical carbon dioxide density on the amount of recovered compounds was confirmed. The use of supercritical $\mathrm{CO}_{2}$ led to a significant reduction in the volume of organic solvent required for extraction.
\end{abstract}

Keywords: chokeberry; extraction; phenolic compounds; pomace; supercritical carbon dioxide

\section{Introduction}

The chokeberry (Aronia melanocarpa (Michx.) Elliot) is a genus of shrub from the Rosaceae family. The plant is native to North American wetlands, however, it is now cultivated worldwide for decorative purposes as well as for food production. The fruit of the chokeberry is often described as a superfood because of its health-promoting properties, including its hypotensive effect, hepatoprotection, and the inhibition of cancer cell proliferation [1]. These properties are connected to the very high levels of phenolic compounds (1.48-7.85 g per $100 \mathrm{~g}$ ), with anthocyanins and proanthocyanidins being the most abundant groups [2-4].

The majority of the phenols are concentrated in the skin of the fruit; therefore, a significant number of these compounds remains in the pomace after juice production [5-8]. The possibility of recovering valuable compounds from chokeberry waste products was investigated by a few research teams. The groups led by Mohammadifakhr [9] and Baranowski [10] focused on using organic solvents to retrieve the phenolics from the pomace, while the goal of Nawirska and Kwaśniewska [11] was to obtain a dietary fiber.

The reactive oxygen species (ROS) are a group of highly active molecules generated as a result of internal and external agents. The most prominent ROS are: singlet oxygen $\left({ }^{1} \mathrm{O}_{2}\right)$, ozone $\left(\mathrm{O}_{3}\right)$, hydrogen peroxide $\left(\mathrm{H}_{2} \mathrm{O}_{2}\right)$, hydroxyl radical $\left({ }^{\bullet} \mathrm{OH}\right)$, superoxide radical $\left(\mathrm{O}_{2}{ }^{\bullet-}\right)$, and nitric oxide $\left(\mathrm{NO} \mathrm{O}^{\bullet}\right.$. 
The main sources of ROS in living organisms are ultraviolet radiation, oxidation of xenobiotics, Fenton-like reactions, and "leakage" of electrons from biochemical processes like photosynthesis and the electron transfer chain. The effects of reactive oxygen species on cell metabolism are often described as an oxidative stress and include: damaging DNA and RNA, lipid peroxidation, and oxidation of amino acids in proteins. The oxidative stress is suspected to play a significant role in neurodegenerative diseases (such as Parkinson's and Alzheimer's diseases), cardiovascular ailments, and in age-related development of cancer [12]. SFE (Supercritical Fluid Extraction) is an emerging technology of separation that uses substances above their critical points as an alternative to organic solvents. Carbon dioxide is the most prominent amongst various solvents used in this method. Its greatest advantages are: limited toxicity, mild critical conditions, chemical inertia, and low cost [13]. The density of supercritical carbon dioxide is an important factor during SFE processing. The influence of this parameter on the extraction yield has been observed by several research teams [14,15].

The use of supercritical carbon dioxide as an extraction solvent can be advantageous against traditional techniques of extraction. The supercritical fluids are characterized by high diffusion coefficients and low viscosity, thus, rates of the extraction can be improved compared to traditional solvent use. The density of supercritical fluids can be easily modified by the alteration of temperature and pressure. Many properties of supercritical fluids are correlated with their density, so the selectivity of extraction can be achieved by application of the proper process parameters [13].

The techniques based on SFE are commonly used in the food industry. The most noteworthy examples are decaffeination of coffee, removal of alcohol from wine and beer, decreasing the amount of fat in meat, enrichment with lipid-soluble vitamins, and production of spice extracts. The costs of processing are generally higher than in other methods; however, they offer exceptional possibilities of acquiring solvent-free products [16]. The supercritical $\mathrm{CO}_{2}$ is also used as a preservation medium [17] and during the micronization of food [18].

The extraction with supercritical carbon dioxide was used to acquire extracts from over 300 plant species [19]. This technique has already been used to isolate health-promoting compounds from the pomace of a few plants, inter alia, grapes [20], tomatoes [21], olives [22], sour cherries [14], and the guelder-rose [23]. To the best knowledge of the authors, this is the first work to be undertaken on the application of supercritical fluids to process chokeberry fruits or pomace.

The present study is a report on the extraction of phenolic compounds from chokeberry pomace using supercritical $\mathrm{CO}_{2}$. The experiments involved determining the level of phenolic compounds and anthocyanins in the extracts obtained, as well as estimating the scavenging activity against two artificial radicals $\mathrm{DPPH}^{\bullet}$ (2,2-diphenyl-1-picrylhydrazyl) and ABTS ${ }^{\bullet+}$ (2,2'-azino-bis(3-ethylbenzothiazoline-6-sulphonic acid)) and three radicals with a physiological significance (hydroxyl radical, superoxide radical, and nitric oxide). The main aims of the study were to maximize the recovery of phenolic compounds in the extracts. The effect of temperature, pressure, and ethanol addition on the yield and antioxidant activity of the extracts was evaluated.

\section{Materials and Methods}

\subsection{Materials}

The chokeberry pomace was obtained in a laboratory-scale process using fruit purchased from a local vendor. A commercial pectinolytic enzyme preparation (Rapidase Smart) was used prior to pressing in accordance to the instructions of the producer $(0.1 \mathrm{~g} / \mathrm{kg}$ of pulp; $1 \mathrm{~h}$ at ambient temperature). The pomace was cut, split into portions, and kept at $-18{ }^{\circ} \mathrm{C}$ until further processing.

The standard of cyanidin-3-O-glucoside was bought from Extrasynthese (Genay, France), while the cyanidin-3-O-galactoside and cyanidin-3-O-arabinoside came from Polyphenol Laboratories (Sandnes, Norway). Carbon dioxide of a technical grade was acquired from a local seller. Other reagents were of analytical grade and were acquired from Sigma-Aldrich (Saint Louis, MO, USA). 


\subsection{Instrumentation}

Supercritical Fluid Extraction was accomplished using an SFE Spe-ed 4 apparatus (Applied Separations, Allentown, PA, USA). For the analyses, a Genesys 10UV spectrophotometer (Thermo Electron Corporation, Waltham, MA, USA) and HPLC equipment: 2695 Separation Module and 2995 Photodiode Assay Detector (Waters, Milford, MA, USA) were used.

\subsection{Design of Experiment and Data Analysis}

The experimental points were selected using an approach proposed by Box and Behnken [24]. Three parameters were investigated during the research: temperature $\left(35,50\right.$, and $\left.65^{\circ} \mathrm{C}\right)$, pressure $(7.5$, 10.0 , and $12.5 \mathrm{MPa})$, and the addition of ethanol to the pomace $(20 \%, 50 \%$, and $80 \% \mathrm{~m} / \mathrm{m}$; calculated as ratio of ethanol and pomace). The densities of $\mathrm{CO}_{2}$ were computed using equations presented by Ouyang [25]. The tested combinations of parameters, along with the corresponding densities and the normalized values, are presented in Table 1.

Design Expert 9 (Stat-Ease, Minneapolis, MN, USA) and Microsoft Excel 2010 (Microsoft, Redmond, WA, USA) were used to analyze the data obtained.

\subsection{Supercritical Fluid Extraction}

The pomace (portions of approximately $10 \mathrm{~g}$ each) were unfrozen, mixed with ethanol (which, therefore, acted as a co-solvent), and inserted into the extraction vessel (internal volume $=20 \mathrm{~mL}$ ). The use of ethyl alcohol was required since the polarity of pure carbon dioxide is too low to efficiently remove phenolic compounds from the matrix.

The extraction procedure comprised two phases: static and dynamic. During the static stage the vessel was filled with supercritical $\mathrm{CO}_{2}$ and thermostated for $15 \mathrm{~min}$. This stage was necessary for stabilization of temperature in the extraction vessel and for enabling a good penetration of a solvent comprising ethanol and $\mathrm{CO}_{2}$ into the matrix. The dynamic stage was $1 \mathrm{~h}$ long with a constant flow of carbon dioxide of approximately $1.8 \mathrm{~g} \mathrm{~min}^{-1}$. The vessel was supplied with a pure carbon dioxide, while the efflux contained both $\mathrm{CO}_{2}$ and $\mathrm{C}_{2} \mathrm{H}_{5} \mathrm{OH}$, thus, composition and polarity of the extractant were changing during the process allowing for the recovery of a wider range of compounds. The total use of carbon dioxide during a single extraction was approximately 120-130 g. After the process, the tubes of the extraction apparatus were flushed with ethyl alcohol to purge any potential residues. The extracts obtained were stored at $-18^{\circ} \mathrm{C}$ until analyzed.

\subsection{Extraction with Organic Solvents}

Two methods of acquiring organic solvent-based extracts were employed. The parameters of the first procedure were chosen to ensure comparability with the conditions of the SFE extraction. The goal of the second approach was determination of the total amount of phenolic compounds present in pomace.

\subsubsection{Comparison of the Extraction Methods}

For the comparative extraction, the portions of pomace (approximately $25 \mathrm{~g}$ ) were mixed with ethyl alcohol and stirred vigorously to guarantee proper mass transfer. The extraction parameters were: temperature $\left(50^{\circ} \mathrm{C}\right)$, ethanol-solid ratio $(50 \% \mathrm{~m} / \mathrm{m})$, and processing time $(1 \mathrm{~h})$.

\subsubsection{Determination of Amount of Phenolic Compounds in the Pomace}

Full recovery of the phenolic compounds present in the pomace was achieved using a protocol described by Francis [26]. The sample was homogenized and extracted with a $1 \%$ solution of hydrochloric acid in methanol. The solid remains were reextracted four times and the extracts obtained were connected. 
Table 1. Composition and activity against selected radicals of the chokeberry extracts obtained under different extraction parameters. Masses refer to the pomace. Abbr:: $T=$ temperature, $p=$ pressure, $c=$ ethyl alcohol addition, $\varrho=$ density, $X_{i}=$ normalized process parameters (in the range from -1 to +1 ), ACNs $=$ anthocyanins, $\mathrm{TPC}=$ total phenolic content, $\mathrm{C} 3 \mathrm{G}=$ cyanidin-3-O-glucoside, $\mathrm{GA}=$ gallic acid, curc $=$ curcumin, querc $=$ quercetin, sorb $=$ sorbitol .

\begin{tabular}{|c|c|c|c|c|c|c|c|c|c|c|c|}
\hline \multirow{3}{*}{ Sample } & \multicolumn{4}{|c|}{ Carbon Dioxide Properties } & \multicolumn{2}{|c|}{ Extract Composition } & \multicolumn{5}{|c|}{ Activity Against } \\
\hline & $T\left(X_{1}\right)$ & $p\left(X_{2}\right)$ & $c\left(X_{3}\right)$ & $\varrho\left(X_{4}\right)$ & ACNs & TPC & $\mathrm{DPPH}^{\bullet}$ & $\mathrm{ABTS}^{\bullet+}$ & $\mathrm{NO}^{\bullet}$ & $\mathrm{O}_{2}^{\bullet-}$ & $\bullet \mathrm{OH}$ \\
\hline & $\left({ }^{\circ} \mathrm{C}\right)$ & (MPa) & $(\% \mathrm{~m} / \mathrm{m})$ & $\left(\mathrm{kg} \mathrm{m}^{-3}\right)$ & $\begin{array}{l}\text { (mg C3G } \\
\text { per 100 g) }\end{array}$ & $\begin{array}{c}\text { (mg GA } \\
\text { per 100 g) }\end{array}$ & $\begin{array}{l}\text { ( } \mu \text { mol Trolox } \\
\text { per } 100 \mathrm{~g})\end{array}$ & $\begin{array}{l}\text { ( } \mu \text { mol Trolox } \\
\text { per } 100 \mathrm{~g})\end{array}$ & $\begin{array}{c}(\mu \mathrm{mol} \text { curc } \\
\text { per } 100 \mathrm{~g})\end{array}$ & $\begin{array}{l}\text { ( } \mu \text { mol querc } \\
\text { per } 100 \mathrm{~g})\end{array}$ & $\begin{array}{c}\text { (mmol sorb } \\
\text { per } 100 \mathrm{~g} \text { ) }\end{array}$ \\
\hline 1 & $50(0)$ & $10.0(0)$ & $50(0)$ & $398(-0.28)$ & 410.3 & 711.4 & 1309.2 & 1247.8 & 24.7 & 648.8 & 41.15 \\
\hline 2 & $50(0)$ & $12.5(+1)$ & $80(+1)$ & $596(+0.33)$ & 749.1 & 1197.7 & 2017.2 & 2007.3 & 20.3 & 848.0 & 49.00 \\
\hline 3 & $50(0)$ & $12.5(+1)$ & $20(-1)$ & $596(+0.33)$ & 341.3 & 680.1 & 987.1 & 1214.1 & 16.2 & 621.8 & 28.41 \\
\hline 4 & $50(0)$ & $7.5(-1)$ & $80(+1)$ & $177(-0.98)$ & 324.0 & 545.4 & - & - & - & - & - \\
\hline 5 & $50(0)$ & $7.5(-1)$ & $20(-1)$ & $177(-0.98)$ & 116.8 & 187.2 & 459.7 & 411.0 & 13.3 & 249.4 & 16.44 \\
\hline 6 & $50(0)$ & $10.0(0)$ & $50(0)$ & $398(-0.28)$ & 430.3 & 802.0 & - & - & - & - & - \\
\hline 7 & $65(+1)$ & $10.0(0)$ & $80(+1)$ & $266(-0.70)$ & 455.5 & 787.2 & - & - & - & - & - \\
\hline 8 & $65(+1)$ & $10.0(0)$ & $20(-1)$ & $266(-0.70)$ & 197.9 & 367.4 & - & - & - & - & - \\
\hline 9 & $35(-1)$ & $10.0(0)$ & $80(+1)$ & $766(+0.86)$ & 1002.4 & 1520.7 & 2907.0 & 3384.1 & 29.0 & 1138.4 & 72.24 \\
\hline 10 & $35(-1)$ & $10.0(0)$ & $20(-1)$ & $766(+0.86)$ & 574.8 & 1002.2 & - & - & - & - & - \\
\hline 11 & $50(0)$ & $10.0(0)$ & $50(0)$ & $398(-0.28)$ & 422.4 & 681.4 & - & - & - & - & - \\
\hline 12 & $65(+1)$ & $12.5(+1)$ & $50(0)$ & $419(-0.22)$ & 437.5 & 801.4 & - & - & - & - & - \\
\hline 13 & $65(+1)$ & $7.5(-1)$ & $50(0)$ & $169(-1.00)$ & 201.6 & 356.4 & 671.0 & 702.4 & 18.7 & 328.4 & 27.28 \\
\hline 14 & $35(-1)$ & $12.5(+1)$ & $50(0)$ & $812(+1.00)$ & 967.7 & 1429.9 & - & - & - & - & - \\
\hline 15 & $35(-1)$ & $7.5(-1)$ & $50(0)$ & $207(-0.88)$ & 406.5 & 641.1 & - & - & - & - & - \\
\hline $\mathrm{S}$ & \multirow{2}{*}{\multicolumn{4}{|c|}{$\begin{array}{l}\text { full extraction of polyphenols with methanol } \\
\text { ethanol extract (ethanol-solid ratio } 50 \% \mathrm{~m} / \mathrm{m} \text { ) }\end{array}$}} & 1812.4 & 3204.4 & 6418.3 & 6877.4 & 54.7 & 2590.7 & 135.77 \\
\hline $\mathrm{T}$ & & & & & 245.3 & 433.0 & 923.1 & 908.6 & 11.9 & 341.1 & 30.12 \\
\hline
\end{tabular}




\subsection{Chemical Analysis of the Samples}

Several factors were chosen for the evaluation of the properties of the obtained extracts. The analysis of composition of extracts included the determination of total phenolic content and anthocyanins (a group of pigments responsible for the intense coloration of chokeberries). The tests employing two artificial radicals $\left(\mathrm{ABTS}^{\bullet+}\right.$ and $\mathrm{DPPH}^{\bullet}$ ) were chosen to monitor the antioxidant activity of the extracts because of their widespread use, regardless of the minor connection with biological activity. The assays investigating the scavenging of ${ }^{\bullet} \mathrm{OH}, \mathrm{O}_{2}{ }^{\bullet}$, and $\mathrm{NO}^{\bullet}$, despite their imperfection, gave the results of a much higher in vivo significance.

The total phenolic content (TPC) was determined using a fast spectrophotometric method described by Gao et al. [27]. The reaction mixtures composed of $0.1 \mathrm{~mL}$ of sample, $2.0 \mathrm{~mL}$ of water, $0.2 \mathrm{~mL}$ of Folin-Ciocalteu reagent, and $1.0 \mathrm{~mL}$ of sodium carbonate solution $(15 \%)$ were incubated for $2 \mathrm{~h}$ at room temperature. The phenolic content was determined by measuring absorbance at $765 \mathrm{~nm}$. The results were expressed as equivalents of gallic acid.

An HPLC method described by Oszmiański was employed for quantifying the anthocyanins [28]. A Sunfire C18 reversed-phase column, $5 \mu \mathrm{m}, 4.6 \times 250 \mathrm{~mm}$ (Waters, Milford, MA, USA) was used at $25{ }^{\circ} \mathrm{C}$ with an appropriate precolumn. The samples were eluted with $4.5 \%$ formic acid in water (A) and acetonitrile (B), with a flow rate of $1.0 \mathrm{~mL}$ per min and the following gradient: $0 \mathrm{~min}-100 \% \mathrm{~A}$; $7 \mathrm{~min}-88 \% \mathrm{~A} ; 15 \mathrm{~min}-88 \% \mathrm{~A} ; 21 \mathrm{~min}-20 \% \mathrm{~A} ; 26 \mathrm{~min}-100 \% \mathrm{~A}$. The anthocyanins were quantified at $520 \mathrm{~nm}$. The concentrations were presented as equivalents of cyanidin-3-O-glucoside.

The scavenging activity against $\mathrm{ABTS}^{\bullet+}$ was measured with a protocol described by Re et al. [29]. The radical cations were generated by preparing a solution composed of $7 \mathrm{mM}$ of ABTS and $2.45 \mathrm{mM}$ of potassium persulfate. After $16 \mathrm{~h}$ of incubation in darkness, the solution was diluted with ethyl alcohol to achieve an absorbance of 0.7 at $734 \mathrm{~nm}$. The $25 \mu \mathrm{L}$ samples were combined with $2.5 \mathrm{~mL}$ of $\mathrm{ABTS}^{\bullet+}$ solution and incubated for $6 \mathrm{~min}$. The degradation of green-colored radical cations was measured at $734 \mathrm{~nm}$. Trolox was chosen as a reference antioxidant.

A method described by Yen and Chen was used to determine the activity against DPPH ${ }^{\bullet}$ [30]. The $0.1 \mathrm{~mL}$ samples were combined with $2 \mathrm{~mL}$ of $\mathrm{DPPH}^{\bullet}$ solution $(1 \mathrm{mM})$ and incubated at ambient temperature for $30 \mathrm{~min}$. The degradation of violet-pigmented radicals was evaluated spectrophotometrically at $517 \mathrm{~nm}$. Trolox was chosen as a reference antioxidant.

The hydroxyl radical scavenging activity of extracts was determined using a method by Kunchandy and Rao [31]. The radicals were generated during the Fenton reaction, which was started by mixing equal volumes of solutions of: EDTA (ethylenediaminetetraacetic acid), $\mathrm{FeCl}_{3}$, ascorbic acid ( $1 \mathrm{mM}$ each), and $\mathrm{H}_{2} \mathrm{O}_{2}(10 \mathrm{mM})$. The $400 \mu \mathrm{L}$ of the mixture was merged with $500 \mu \mathrm{L}$ of sample and $100 \mu \mathrm{L}$ of deoxy-2-ribose solution $(28 \mathrm{mM})$. After $1 \mathrm{~h}$ of thermostating at $37^{\circ} \mathrm{C}, 1 \mathrm{~mL}$ of trichloroacetic acid and $1 \mathrm{~mL}$ of thiobarbituric acid were added and the mixture was incubated at $100{ }^{\circ} \mathrm{C}$ for $20 \mathrm{~min}$. After cooling, the amount of oxidized deoxy-2-ribose was measured spectrophotometrically at $532 \mathrm{~nm}$. The results were presented as equivalents of sorbitol.

A method described by Robak and Gryglewski was used to determine the activity against the superoxide radical [32]. The sample $(250 \mu \mathrm{L})$ was mixed with $250 \mu \mathrm{L}$ of $0.45 \mathrm{mM}$ NADH (nicotinamide adenine dinucleotide), $250 \mu \mathrm{L}$ of $0.15 \mathrm{mM}$ nitroblue tetrazolium and $1 \mathrm{~mL}$ of phosphate-buffered saline. The chemical reaction was started by adding $250 \mu \mathrm{L}$ of $0.12 \mathrm{mM}$ phenazine methosulfate. The mixture was thermostated for $5 \mathrm{~min}$ at ambient temperature and the absorbance was determined at $560 \mathrm{~nm}$. The scavenging activity was presented as equivalents of quercetin.

The scavenging activity against nitric oxide was determined with a method of Marcocci et al. [33]. The procedure is based on the fact that, in solutions, nitroprusside ions spontaneously release nitric oxide, which is subsequently transformed into nitrite ions by atmospheric oxygen. The particular compounds are able to neutralize $\mathrm{NO}$ molecules before they are oxidized to $\mathrm{NO}_{2}{ }^{-}$, hence the scavenging properties of the samples can be expressed as a difference in the amount of nitrites created. During the assay, equal volumes of the extract and $10 \mathrm{mM}$ sodium nitroprusside solution were mixed and thermostated for $2 \mathrm{~h}$ at $37^{\circ} \mathrm{C}$. Afterwards, $1 \mathrm{~mL}$ of the solution was mixed with $1 \mathrm{~mL}$ 
of Griess' reagent for nitrites and incubated for one half hour at room temperature. The formation of red-colored azo dye was measured spectrophotometrically at $546 \mathrm{~nm}$. The scavenging activity was expressed as equivalents of coumarin.

\section{Results and Discussion}

\subsection{Effect of Process Conditions on TPC}

Phenolic compounds are a very wide and divergent group. Therefore, an accurate evaluation of their content via HPLC methods would be very toilsome. As a result, the most common method of evaluating their content, a spectrophotometric test using Folin-Ciocalteu reagent, was used. The selectivity of this test is low: the presence of thiols, proteins, and some inorganic ions can lead to overestimating the result [34]; however, in the investigated system, the polarity of extraction medium was too low to co-extract significant amounts of such compounds. The results are listed in Table 1.

RSM (Response Surface Methodology) was selected as a mathematical method of optimization [35]. The yield of phenolic compounds was connected with the process parameters using the equation (Equation (1)):

$$
Y=a_{0}+a_{1} X_{1}+a_{2} X_{2}+a_{3} X_{3}+a_{11} X_{1}^{2}+a_{22} X_{2}^{2}+a_{33} X_{3}^{2}+a_{12} X_{1} X_{2}+a_{13} X_{1} X_{3}+a_{23} X_{2} X_{3}
$$

where: $Y=$ the yield of the extraction, $X_{i}=$ normalized process parameters (as in Table 1), and $a_{i}=$ model constants.

The values of the model constants obtained during the optimization are presented in Table 2 along with a statistical analysis of their significance. Amongst the process parameters and their combinations, three significantly (at $p \leq 0.05$ ) affected the yield of the extraction: $X_{1}, X_{2}$, and $X_{3}$. Broadening the significance level to $p \leq 0.10$ revealed that $X_{1}^{2}$ and $X_{1} X_{2}$ also influenced the outcome of the process.

An increase in the recovery of phenolic compounds was obtained by minimizing the extraction temperature, and maximizing the addition of ethanol and pressure. The highest yield ( $1.52 \mathrm{~g}$ per $100 \mathrm{~g}$ of pomace) was acquired at $35^{\circ} \mathrm{C}, 10 \mathrm{MPa}$, and $80 \% \mathrm{~m} / \mathrm{m}$ ethanol addition. The calculations showed that better results ( $1.78 \mathrm{~g}$ per $100 \mathrm{~g}$ of pomace) would be acquired for $35^{\circ} \mathrm{C}, 12.5 \mathrm{MPa}$ and $80 \%$ $\mathrm{m} / \mathrm{m}$ of ethyl alcohol (parameter set not tested due to using the Box-Behnken approach). A graphical representation of the results is shown in Figure 1.

The values of the yield obtained by model computations were comparable with the empirical data. As an illustration, at $35^{\circ} \mathrm{C}, 10 \mathrm{MPa}$, and $80 \% \mathrm{~m} / \mathrm{m}$ ethanol addition, the computed yield $(1.54 \mathrm{~g}$ per $100 \mathrm{~g}$ ) was only about $1 \%$ higher than the result of the experiment.

Table 2. Summary of three-parameter optimization of the extraction process.

\begin{tabular}{ccc}
\hline Model Constant & Value & Significance $(p$-Value) \\
\hline $\mathrm{a}_{0}$ & 731.60 & - \\
$\mathrm{a}_{1}$ & -285.19 & 0.0007 \\
$\mathrm{a}_{2}$ & 297.38 & 0.0006 \\
$\mathrm{a}_{3}$ & 226.76 & 0.0011 \\
$\mathrm{a}_{11}$ & 171.19 & 0.0587 \\
$\mathrm{a}_{22}$ & -85.59 & 0.1424 \\
$\mathrm{a}_{33}$ & 16.59 & 0.7920 \\
$\mathrm{a}_{12}$ & -95.95 & 0.0908 \\
$\mathrm{a}_{13}$ & -24.68 & 0.7144 \\
$\mathrm{a}_{23}$ & 39.85 & 0.6036 \\
Model F-Value & 15.229 & 0.0038 \\
\hline
\end{tabular}




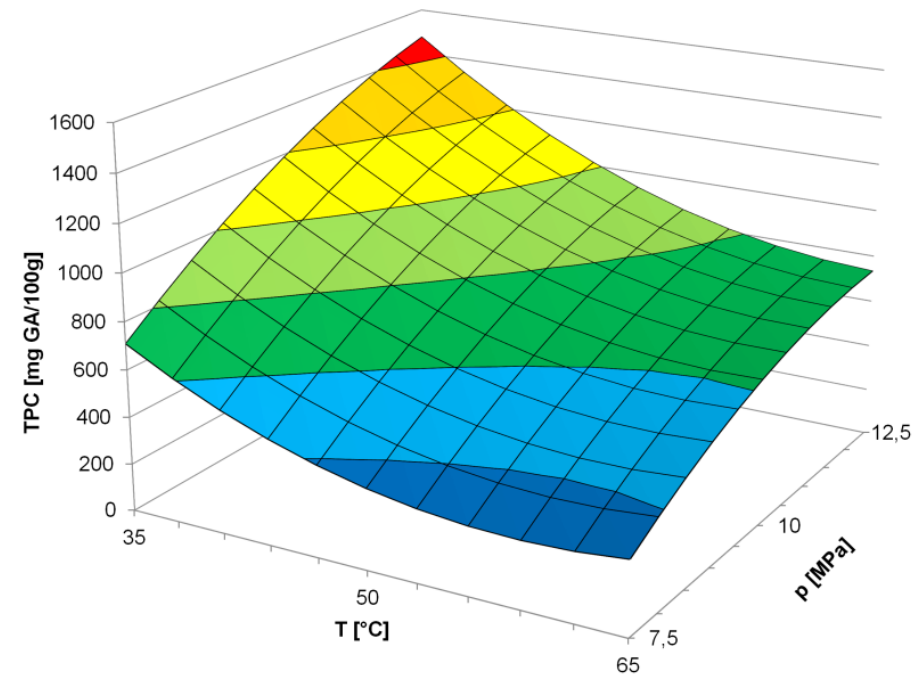

Figure 1. Effect of the temperature and pressure of extraction on the yield of phenolic compounds during the Supercritical Fluid Extraction (SFE) of chokeberry pomace $(50 \% \mathrm{~m} / \mathrm{m}$ addition of ethyl alcohol). Abbr.: GA = gallic acid, TPC $=$ total phenolic content, $T=$ temperature, $p=$ pressure.

The presented approach allowed good modelling of empirical data, however, it was not able to explain clearly what mechanisms were responsible for the results, for e.g., is the effect of pressure connected with an increase of density? To test the hypothesis about the impact of solvent density, the computations were repeated using the density of $\mathrm{CO}_{2}$ instead of the temperature and pressure.

The yield of phenolic compounds was connected with the process parameters using the equation (Equation (2), symbols as above):

$$
Y=a_{0}+a_{3} X_{3}+a_{4} X_{4}+a_{33} X_{3}^{2}+a_{44} X_{4}^{2}+a_{34} X_{3} X_{4}
$$

The values of the model constants acquired and their significance are presented in Table 3. Two of the process parameters were significant: $X_{3}$ and $X_{4}$. The model $F$-value was superior to the one obtained during the first calculation.

An increase in the recovery of phenolic compounds was obtained by maximizing the addition of ethanol and the density of $\mathrm{CO}_{2}$. A graphical representation of the results is shown in Figure 2.

The values of the yield obtained by model computations were very close to the empirical findings. The adjustment improved the fit in comparison with the earlier calculations, the $F$-values of both models (15.229 versus 84.660 ) confirm the results. The computed yield at $35^{\circ} \mathrm{C}, 10 \mathrm{MPa}$, and $80 \% \mathrm{~m} / \mathrm{m}$ ethanol addition (density of ca. $766 \mathrm{~kg} \cdot \mathrm{m}^{3}$ ) was the same as the experimental result (1.52 g per $100 \mathrm{~g}$ ).

Table 3. Summary of two-parameter optimization of the extraction process.

\begin{tabular}{ccc}
\hline Model Constant & Value & Significance $(p$-Value) \\
\hline $\mathrm{a}_{0}$ & 882.60 & - \\
$\mathrm{a}_{3}$ & 232.08 & $<0.0001$ \\
$\mathrm{a}_{4}$ & 470.51 & $<0.0001$ \\
$\mathrm{a}_{33}$ & -70.79 & 0.1645 \\
$\mathrm{a}_{44}$ & 55.64 & 0.2467 \\
$\mathrm{a}_{34}$ & 43.47 & 0.2897 \\
Model $F$-value & 84.660 & $<0.0001$ \\
\hline
\end{tabular}




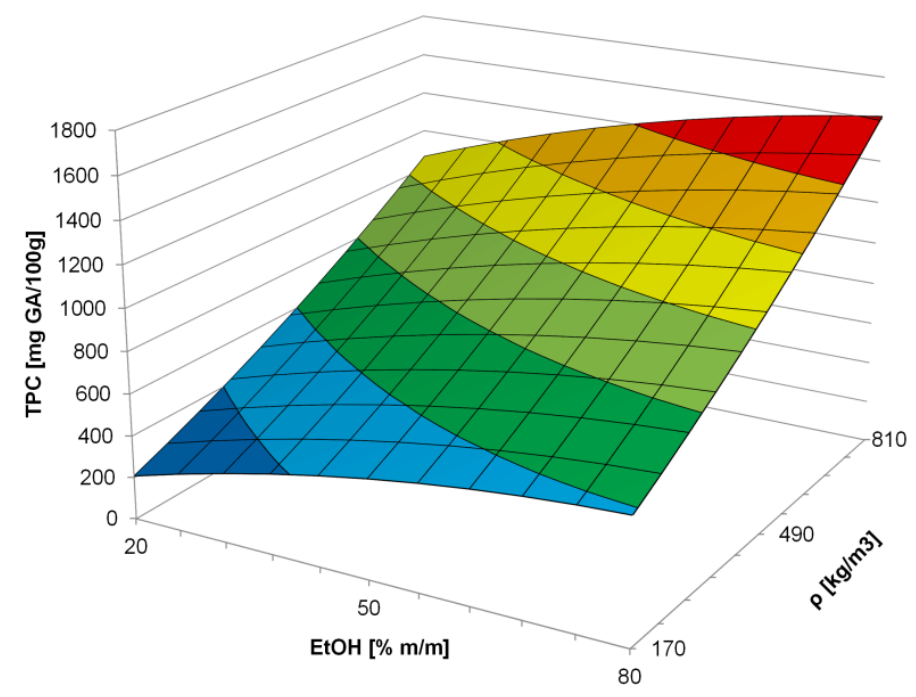

Figure 2. Effect of the addition of ethanol and density of the carbon dioxide on the yield of phenolic compounds during the SFE of chokeberry pomace $(50 \% \mathrm{~m} / \mathrm{m}$ addition of ethyl alcohol). Abbr.: GA = gallic acid, TPC = total phenolic content, $T=$ temperature, $p=$ pressure.

\subsection{Anthocyanin Content}

A quantitative analysis of the anthocyanins in the extracts was carried out using high performance liquid chromatography (Figure 3). The galactoside, glucoside, and arabinoside of cyanidin were identified using certified standards, and cyanidin-3-xyloside by comparing its retention time and quantity to the data in literature $[3,28]$.

Anthocyanins accounted for $50 \%-67 \%$ of the total phenolics in the extracts collected. The ratio of individual anthocyanins was constant for all the samples obtained. A strong correlation was found between the TPC and anthocyanin content $\left(R^{2}=0.9788\right)$.

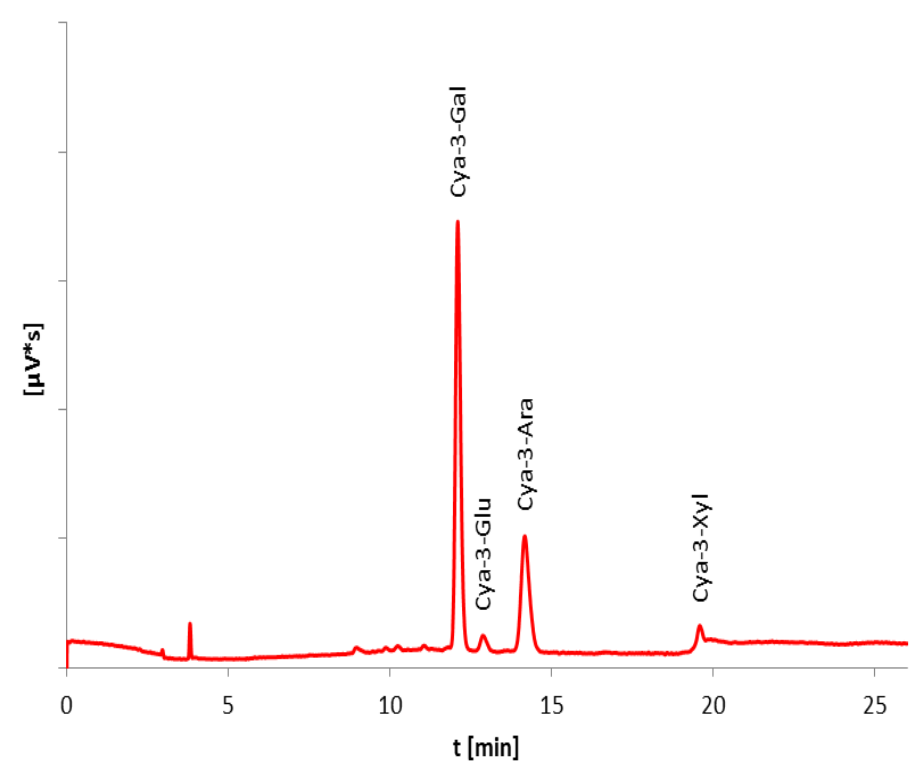

Figure 3. Anthocyanin compounds present in the SPE extracts from chokeberry pomace. Abbr.: Cya-3-Gal = cyanidin-3-galactoside, Cya-3-Glu = cyanidin-3-glucoside, Cya-3-Ara = cyanidin-3arabinoside, Cya-3-Xyl = cyanidin-3-xyloside, $\mathrm{t}=$ time. 


\subsection{Free Radical Scavenging}

Among the methods used to estimate the antioxidative properties in vitro, the most popular are those based on the scavenging of free radicals. The most prevalent are cheap, simple, and fast assays exploiting $\mathrm{ABTS}^{\bullet+}$ and $\mathrm{DPPH}^{\bullet}$ radicals; however, the structure of artificial radicals varies from the naturally occurring reactive oxygen species, therefore, the in vivo significance of the results can be disputed [36]. Therefore, the activity against three radicals of major biological significance was also determined. Detailed results are presented in Table 1 while a summary and interpretation of results are shown in Table 4.

Table 4. Potential of the extracts from chokeberry pomace to scavenge selected free radicals.

Abbr: $\quad \mathrm{TPC}=$ total phenolic content, $\mathrm{GAE}=$ gallic acid equivalents, $\mathrm{IC}_{50}=$ half maximal inhibitory concentration.

\begin{tabular}{|c|c|c|c|c|c|}
\hline Parameter & DPPH• & $\mathrm{ABTS}^{\bullet+}$ & NO• & $\mathrm{O}_{2}^{-\bullet}$ & $\mathrm{OH}^{\bullet}$ \\
\hline $\begin{array}{l}\text { reference } \\
\text { compound }\end{array}$ & Trolox & Trolox & curcumin & quercetin & sorbitol \\
\hline $\begin{array}{l}\text { equivalent of } 100 \mathrm{~g} \\
\text { of pomace }\end{array}$ & $459.7-2907.0 \mu \mathrm{mol}$ & $411.0-3384.1 \mu \mathrm{mol}$ & $13.3-29.0 \mu \mathrm{mol}$ & $249.4-1138.4 \mu \mathrm{mol}$ & $16.44-72.24 \mathrm{mmol}$ \\
\hline $\begin{array}{l}\text { equivalent of } \\
1 \mathrm{~g} \text { of GAE }\end{array}$ & $1.87 \pm 0.33 \mathrm{mmol}$ & $1.93 \pm 0.23 \mathrm{mmol}$ & $36.3 \pm 21.4 \mu \mathrm{mol}$ & $0.92 \pm 0.22 \mathrm{mmol}$ & $58.7 \pm 19.5 \mathrm{mmol}$ \\
\hline $\begin{array}{l}\mathrm{IC}_{50} \text { of reference } \\
\text { compound }\end{array}$ & $\begin{array}{l}23.3 \mu \mathrm{mol} / \mathrm{L} \\
(5.83 \mathrm{mg} / \mathrm{L})\end{array}$ & $\begin{array}{l}10.4 \mu \mathrm{mol} / \mathrm{L} \\
(2.60 \mathrm{mg} / \mathrm{L})\end{array}$ & $\begin{array}{l}33.0 \mu \mathrm{mol} / \mathrm{L} \\
(12.16 \mathrm{mg} / \mathrm{L})\end{array}$ & $\begin{array}{l}3.89 \mu \mathrm{mol} / \mathrm{L} \\
(1.18 \mathrm{mg} / \mathrm{L})\end{array}$ & $\begin{array}{c}27.1 \mathrm{mmol} / \mathrm{L} \\
(4.94 \mathrm{~g} / \mathrm{L})\end{array}$ \\
\hline $\begin{array}{l}\text { GAE for } 50 \% \text { of } \\
\text { inhibition }\end{array}$ & $12.46 \mathrm{mg} / \mathrm{L}$ & $5.39 \mathrm{mg} / \mathrm{L}$ & $909.09 \mathrm{mg} / \mathrm{L}$ & $1.63 \mathrm{mg} / \mathrm{L}$ & $461.67 \mathrm{mg} / \mathrm{L}$ \\
\hline $\begin{array}{l}\text { correlation } \\
\text { with TPC }\end{array}$ & 0.9715 & 0.9490 & 0.6249 & 0.9803 & 0.9248 \\
\hline
\end{tabular}

Extracts from Aronia melanocarpa showed comparable scavenging properties in both assays implementing the use of artificial radicals $\left(\mathrm{ABTS}^{\bullet+}\right.$ and $\mathrm{DPPH}^{\bullet}$ ). The activity of phenolics was approximately two times smaller than that exhibited by Trolox. Both tests showed a similar activity range and a high correlation with the concentration of phenolic compounds.

The scavenging capacity of the hydroxyl radical was also well correlated with the phenolic content. However, the results were affected by the properties of this reactive oxygen species; it is excessively reactive and can oxidize the vast majority of organic molecules [37]. All compounds present in the extracts (including non-phenolics) increase the scavenging activity against $\mathrm{OH}^{\bullet}$, however, the concentrations required for efficient protection are not possible to achieve in living cells. Therefore, the only effective method of defense against the hydroxyl radical is by hindering its formation from other reactive oxygen species.

Research on the scavenging activity against the superoxide radical showed that chokeberry extracts are exceptionally good neutralizers of these molecules. A concentration of phenolics as low as $1.6 \mathrm{mg} / \mathrm{L}$ (expressed as equivalents of gallic acid) was able to scavenge more than $50 \%$ of radicals. This parameter showed the highest correlation with total phenolic content $\left(R^{2}=0.9803\right)$.

Nitric oxide is a distinguished reactive oxygen species. It shows very limited activity against macromolecules, although it can react with other radicals, which induces the formation of more dangerous molecules, e.g., peroxynitrite $\left(\mathrm{ONOO}^{-}\right)$[38]. The phenolic compounds obtained from Aronia melanocarpa turned out to be weak inhibitors of $\mathrm{NO}^{\bullet}$. The correlation between the TPC and activity against nitric oxide was moderate $\left(R^{2}=0.6249\right)$.

\subsection{Comparison of SFE and Solvent Extraction}

The phenolic content in chokeberry pomace was $3204 \mathrm{mg}$ GA per $100 \mathrm{~g}$. The recovery of solvent extraction was only $13.5 \%$, while supercritical $\mathrm{CO}_{2}$ modified with ethanol (with the same ethanol-pomace ratio of 0.5 ) was able to elute $11.1 \%-44.6 \%$ of phenolics. This part of the experiments, with the use of high densities of $\mathrm{CO}_{2}$, gave significantly higher yields than that from solvent extraction. 
The extracts obtained with both methods exhibited a similar quantity of anthocyanins and radical scavenging activity when converted to $1 \mathrm{~g}$ of gallic acid equivalent. The output of solvent extraction could be undoubtedly increased by utilizing greater amounts of solvent; although one of the goals of the project was to reduce the use of these substances.

\section{Conclusions}

All the parameters tested had a significant effect on the yield of supercritical carbon dioxide extraction. Generally, superior recovery of the phenolic compounds was achieved at a higher pressure, lower temperature, and adding larger quantities of ethyl alcohol. The impact of $\mathrm{CO}_{2}$ density on the efficiency of the extraction, presented in the literature [14,15], was confirmed.

The two-parameter model proved to be appropriate for the description of the process (the $F$-value of the model was 84.660). The crucial properties of the extracts, anthocyanin content and scavenging of the reactive oxygen species, were highly correlated with the total phenolic content. The use of $\mathrm{CO}_{2}$ will allow for collecting higher amounts of phenolics from the pomace with the same consumption of organic solvents.

The obtained extracts exhibited very high scavenging activity against most of the tested radicals with an exception of nitric oxide. A role of oxidative stress in the process of aging and pathogenesis of many ailments, including atherosclerosis, inflammations, ischemic diseases, and certain tumors, has been postulated [39]. The high content of antioxidant phenolics suggest that use of the extracts as food fortifiers or diet supplements may have a positive effect on the heath of consumers [40]. The results acquired are similar to those found in a previous paper by our team concerning the extraction of sour cherry pomace [14]. In both cases, the influence of the process parameters on the yield was comparable, so these results may suggest that the extraction of other berries using supercritical $\mathrm{CO}_{2}$ would occur in a similar way.

Author Contributions: Łukasz Woźniak designed experiments; Łukasz Woźniak and Krystian Marszałek performed the experiments; Łukasz Woźniak analyzed data wrote the article; Sylwia Skapska and Renata Jedrzejczak provided critical revision of the article.

Conflicts of Interest: The authors declare no conflict of interest.

\section{References}

1. Kulling, S.E.; Rawel, H.M. Chokeberry (Aronia melanocarpa)—A review on the characteristic components and potential health effects. Planta Med. 2008, 74, 1625-1634. [CrossRef] [PubMed]

2. Zheng, W.; Wang, S.Y. Oxygen radical absorbing capacity of phenolics in blueberries, cranberries, chokeberries, and lingonberries. J. Agric. Food Chem. 2003, 51, 502-509. [CrossRef] [PubMed]

3. Oszmiański, J.; Wojdyło, A. Aronia melanocarpa phenolics and their antioxidant activity. Eur. Food Res. Technol. 2005, 221, 809-813. [CrossRef]

4. Wu, X.; Gu, L.; Prior, L.R.; McKay, S. Characterization of anthocyanins and proanthocyanidins in some cultivars of Ribes, Aronia, and Sambucus and their antioxidant capacity. J. Agric. Food Chem. 2004, 52, 7846-7856. [CrossRef] [PubMed]

5. Sójka, M.; Kołodziejczyk, K.; Milala, J. Polyphenolic and basic chemical composition of black chokeberry industrial by-products. Ind. Crops Prod. 2013, 51, 77-86. [CrossRef]

6. Gervasi, T.; Oliveri, F.; Gottuso, V.; Squadrito, M.; Bartolomeo, G.; Cicero, N.; Dugo, G. Nero d'Avola and Perricone cultivars: Determination of polyphenols, flavonoids and anthocyanins in grapes and wines. Nat. Prod. Res. 2016, 30, 2329-2337. [CrossRef] [PubMed]

7. Di Stefano, V.; Avellone, G.; Bongiorno, D.; Indelicato, S.; Massenti, R.; Lo Bianco, R. Quantitative evaluation of the phenolic profile in fruits of six avocado (Persea americana) cultivars by ultra-high-performance liquid chromatography-heated electrospray-mass spectrometry. Int. J. Food Prop. 2016, 30. [CrossRef]

8. Alesci, A.; Cicero, N.; Salvo, A.; Palombieri, D.; Zaccone, D.; Dugo, G.; Bruno, M.; Vadalá, R.; Lauriano, E.R.; Pergolizzi, S. Extracts deriving from olive mill waste waer and their effects on the liver of the goldfish Carassius aureus fed with hypercholesterolemic diet. Nat. Prod. Res. 2014, 28, 1343-1349. [CrossRef] [PubMed] 
9. Mohammadifakhr, M.; Parjikolaei, B.R.; Roda-Serrat, M.C.; Norddahl, B. Production of anthocyanin from chokeberry (Aronia melanocarpa) pomace by extraction, enzymatic treatment, and membrane filtration. In Proceedings of the Euromembrane 2015, Aachen, Germany, 6-10 September 2015.

10. Baranowski, K.; Baca, E.; Salamon, A.; Michałowska, D.; Meller, D.; Karaś, M. Possibilities of retrieving and making a practical use of phenolic compounds from the waste products: Black currant and chokeberry pomace and spent hops. Zywnosc Nauka Technol. Jakosc 2009, 65, 100-109.

11. Nawirska, A.; Kwaśniewska, M. Dietary fiber fractions from fruit and vegetable processing waste. Food Chem. 2005, 91, 221-225. [CrossRef]

12. Bartosz, G. Druga Twarz Tlenu: Wolne Rodniki w Przyrodzie; Wydawnictwo Naukowe PWN: Warsaw, Poland, 2006.

13. Taylor, L.T. Supercritical Fluid Extraction; Wiley: New York, NY, USA, 1996.

14. Woźniak, Ł.; Marszałek, K.; Skapska, S. Extraction of phenolic compounds from sour cherry pomace with supercritical carbon dioxide: Impact of process parameters on the composition and antioxidant properties of extracts. Sep. Sci. Technol. 2016, 51, 1472-1479. [CrossRef]

15. Murga, R.; Sanz, M.T.; Beltrán, S.; Cabezas, J.L. Solubility of some phenolic compounds contained in grape seeds, in supercritical carbon dioxide. J. Supercrit. Fluids 2002, 23, 113-121. [CrossRef]

16. Brunner, G. Supercritical fluids: Technology and application to food processing. J. Food Eng. 2005, 67, 21-33. [CrossRef]

17. Ferrentino, G.; Spilimbergo, S. High pressure carbon dioxide pasteurization of solid foods: Current knowledge and future outlooks. Trends Food Sci. Technol. 2011, 22, 427-441. [CrossRef]

18. Weidner, E. High pressure micronization for food applications. J. Supercrit. Fluids 2009, 47, 556-565. [CrossRef]

19. De Melo, M.M.R.; Silvestre, A.J.D.; Silva, C.M. Supercritical fluid extraction of vegetable matrices: Applications, trends and future perspectives of a convincing green technology. J. Supercrit. Fluids 2014, 92, 115-176. [CrossRef]

20. Pinelo, M.; Ruiz-Rodriguez, A.; Sineiro, J.; Señoráns, F.J.; Reglero, G.; Nuñez, M.J. Supercritical fluid and solid-liquid extraction of phenolic antioxidants from grape pomace: A comparative study. Eur. Food Res. Technol. 2007, 226, 199-205. [CrossRef]

21. Huang, W.; Li, Z.; Niu, H.; Li, D.; Zhang, J. Optimization of operating parameters for supercritical carbon dioxide extraction of lycopene by response surface methodology. J. Food Eng. 2008, 89, 298-302. [CrossRef]

22. Stavroulias, S.; Panayiotou, C. Determination of optimal conditions for the extraction of squalene from olive pomace with supercritical $\mathrm{CO}_{2}$. Chem. Biochem. Eng. Q. 2005, 19, 373-381.

23. Kraujalis, P.; Kraujalienè, V.; Kazernavičiūtè, R.; Venskutonis, P.R. Supercritical carbon dioxide and pressurized liquid extraction of valuable ingredients from Viburnum opulus pomace and berries and evaluation of product characteristics. J. Supercrit. Fluids 2017, 112, 99-108. [CrossRef]

24. Box, G.E.P.; Behnken, D.W. Some new three level designs for the study of quantitative variables. Technometrics 1960, 2, 455-475. [CrossRef]

25. Ouyang, L.B. New correlations for predicting the density and viscosity of supercritical carbon dioxide under conditions expected in carbon capture and sequestration operations. Open Pet. Eng. J. 2011, 4, 13-21. [CrossRef]

26. Francis, F.J. Analysis of anthocyanins. In Anthocyanins as Food Colors; Markakis, P., Ed.; Academic Press Inc.: New York, NY, USA, 1982.

27. Gao, X.; Ohlander, M.; Jeppson, N.; Björk, L.; Trajkovski, V. Changes in antioxidant effects and their relationship to phytonutrients in fruits of sea buckthorn (Hippophaerhamnoides L.) during maturation. J. Agric. Food Chem. 2000, 48, 1485-1490. [CrossRef] [PubMed]

28. Oszmiański, J. Stabilization and application of anthocyanin chokeberry dye to colouring of beverages. Acta Sci. Pol. Technol. Aliment. 2002, 1, 37-45.

29. Re, R.; Pellegrini, N.; Proteggente, A.; Pannala, A.; Yang, M.; Rice-Evans, C. Antioxidant activity applying an improved ABTS radical cation decolorization assay. Free Radic. Biol. Med. 1999, 26, 1231-1237. [CrossRef]

30. Yen, G.C.; Chen, H.Y. Antioxidant activity of various tea extracts in relation to their antimutagenicity. J. Agric. Food Chem. 1995, 43, 27-32. [CrossRef]

31. Kunchandy, E.; Rao, M.N.A. Oxygen radical scavenging activity of curcumin. Int. J. Pharm. 1990, 58, $237-240$. [CrossRef] 
32. Robak, J.; Gryglewski, R.J. Flavonoids are scavengers of superoxide anions. Biochem. Pharmacol. 1988, 37, 837-841. [CrossRef]

33. Marcocci, L.; Maguire, J.L.; Droy-Lefaix, M.T.; Packer, L. The nitric oxide scavenging properties of Gingko biloba extract EGb 761. Biochem. Biophys. Res. Commun. 1994, 201, 748-755. [CrossRef] [PubMed]

34. Everette, J.D.; Bryant, Q.M.; Green, A.M.; Abbey, Y.A.; Wangila, G.W.; Walker, R.B. A thorough study of reactivity of various compound classes towards the Folin-Ciocalteu reagent. J. Agric. Food Chem. 2010, 58, 8139-8144. [CrossRef] [PubMed]

35. Bezerra, M.A.; Santelli, R.E.; Oliveira, E.P.; Villar, L.S.; Escaleira, L.A. Response Surface Methodology (RSM) as a tool for optimization in analytical chemistry. Talanta 2008, 76, 965-977. [CrossRef] [PubMed]

36. Karadag, A.; Ozcelik, B.; Saner, S. Review of methods to determine antioxidant capacities. Food Anal. Methods 2009, 2, 41-60. [CrossRef]

37. Sies, H. Oxidative stress: Oxidants and antioxidants. Exp. Physiol. 1997, 82, 291-295. [CrossRef] [PubMed]

38. Squadrito, G.L.; Pryor, W.A. Oxidative chemistry of nitric oxide: The roles of superoxide, peroxynitrite, and carbon dioxide. Free Rad. Biol. Med. 1998, 25, 392-403. [CrossRef]

39. Lobo, V.; Patil, A.; Phatak, A.; Chandra, N. Free radical, antioxidants and functional foods: Impact on human health. Pharmacogn. Rev. 2010, 4, 118-126. [CrossRef] [PubMed]

40. Yao, L.H.; Jiang, Y.M.; Shi, J.; Tomás-Barberán, F.A.; Datta, N.; Singanusong, R.; Chen, S.S. Flavonoids in food and their health benefits. Plant Food Hum. Nutr. 2004, 59, 113-122. [CrossRef]

(C) 2017 by the authors. Licensee MDPI, Basel, Switzerland. This article is an open access article distributed under the terms and conditions of the Creative Commons Attribution (CC BY) license (http:/ / creativecommons.org/licenses/by/4.0/). 